\title{
PEMANFAATAN LIMBAH TAFU (AIR TAHU) SEBAGAI KOMBORAN SAPI PENGGEMUKAN DAN PENDAPATAN PENGUSAHA TAHU DI PEDESAAN
}

\author{
Gatot Murdjito ${ }^{i}$
}

\section{INTISARI}

Penelitian ini bertujuan untuk mengetahui pengaruh perlakuan pemanfaatan limbah tahu (air tahu) untuk komboran penggemukan sapi Peranakan Onggole (PO) dan sebagai pendapatan pengusaha talu di pedesaan. Enam ekor sapi PO jantan umur sekitar satu tahun Jibagi secara acak ke dalam dua kelompok perlakuan pakan dengan berat rerata kelompok yang hampir sama. Kelompok I Jiberi perlakuan pakan rumput gajalı, komboran katul yang dicampur air. Kelompok II diberi pakan rumput gajah, komboran katul yang dicampur air tahu (limbah tahu). Hasil penelitian menunjukkan bahwa analisis kimiawi limbah tahu mengandung $42,4 \%$ protein, $2,1 \%$ lemak dan abu $25,1 \%$. Konsumsi bahan kering, abu, lemak, protein, serat kasar dan ETN limbah air tahu lebih tinggi dibanding dengan kontrol. Tidak terdapat perbedaan pertambahan berat badan harian antara perlakuan dengan kontrol $(0,69 \mathrm{~kg}$ vs $0,52 \mathrm{~kg} / \mathrm{hari} /$ ekor $)$. Konversi dan efisiensi pakan sapi kelompok perlakuan lebih tinggi dibanding kontrol. Keuntungan yang diperoleh dari kelompok perlakuan sapi yang mendapat komboran air tahu lebih tinggi (Rp1.015,00/hari) dibanding kontrol (Rp.370,00). Berdasarkan penelitian dapat disimpulkan bahwa pemanfaatan limbah tahu (air tahu) sebagai komboran penggemukan sapi akan meningkatkan efisiensi pakan, dan keuntungan yang diperoleh lebih besar bila dibandingkan dengan kombor menggunakan air biasa.

(Kata kunci: Komboran air tahu, Sapi PO jantan, Kenaikan berat badan.)

' Fakultas Peternakan UGM, Yogyakarta 55281 


\section{THE USE OF TOFU WASTE FOR BEEF CATTLE FATTENING AND MARGINAL PROFITS OF TOFU INDUSTRY IN RURAL AREA}

\section{ABSTRACT}

The objective of this study were to know the use of tofu waste for "Onggole" crossbred cattle (PO) tattening and marginal profits of tofu industry in rural area. Six males of PO cattle (more less 12 month old) were randomly divided into 2 groups (Group I and group II). Group I was treated with elephant grass and rice brand mixed will water, where as group II was fed with elephant grass and rice brand mixed with tofu waste plus water. Results showed that tofu waste analysis consisted of $42.4 \%$ protein, $2.1 \%$ fat and $15.1 \%$ ash. Dry matter consumption, ash, fat, protein, crude fiber and nitrogen free exiractive matters of tolu waste was higher compared to control (Group I). Group I and II (0.52 versus 0.69 $\mathrm{kgs} / \mathrm{d} / \mathrm{head}$ ). Feed conversion and feed efficiency were higher group II rather than group I. Marginal profits were Rp1,015.00/d and Rp.370,00/d for groups II and I respectively. It was concluded that tofu waste for beef cattle fattening could increase feed afficiency and profits of tofu industry in rural area.

(Key words: Tolu waste, Male PO cattle and Weight gain.)

\section{Penduhuluan}

Pada dekade tahun terakhir ini, agrobisnis menjadi fokus perhatian pemerintah maupun masyarakat, dengan harapan bahwa dari mata rantai kegiatan agrobisnis, dapat memberikan kontribusi dalam peningkatan devisa, perluasan kesempatan kerja dan peningkatan kesejahteraan masyarakat. Dewasa ini, agrobisnis di bidang penggemukan sapi potong telah menunjukkan perkembangan pesat. Banyak investor baik dari kalangan swasta maupun BUMN menanamkan modalnya di bidang penggemukan sapi potong. Demikian pula banyak dari kalangan peternak, telah menunjukkan minatnya yang besar dalam usaha penggenukan sapi potong. Menurut Tillman et al, (1984) penggemukan adalah suatu istilah untuk menggambarkan keadaan hewan pada saat-saat terakhir stadium pertumbuhannya. Penggemukan tidak berarti menyebabkan hewan hanya menimbun lemak saja. Semua hewan yang dimaksudkan untuk diambil dagingnya akan dipotong jauh sebelum pertambahan berat badan mengandung banyak lemak.

Kualitas pakan merupakan salah satu faktor yang menentukan kecepatan pertambahan berat badan sapi disamping faktor-faktor lain seperti: bangsa, jenis kelamin, keturunan dan cara pemeliharaan (Reksohadiprodjo, 1981). Usaha peningkatan produktivitas harus diimbangi oleh penyediaan pakan yang baik dengan harga yang relatif murah.

Penggunaan limbah cair tahu diharapkan dapat meningkatkan pertambahan berat badan pada penggemukan sapi potong disamping juga dapat menanggulangi masalah pencemaran.

Tahu merupakan hasil olahan dari bahan dasar kedelai melalui proses pengendapan atau penggumpalan oleh bahan penggumpal. Pengusaha tahu dan tempe banyak bermunculan baik di kota maupun di 
pedesaan, karena merupakan makanan yang mengandung protein nabati tinggi yang disenangi masyarakat dan harganya relatif murah. Problem yang dihadapi oleh pengusala tahu, adalah limbah cair (air tahu) yang mengganggu lingkunagn (pencemaran) karena setiap memproses tahu untuk 1 kilogram kedele menghasilkan air tahu 10 liter, sehingga banyak warga di sekitar pabrik tahu yang melakukan protes masalah limbah cair tahu, karena cairan tahu yang dibuang di tempat pembuangan setiap harinya menimbulkan bau yang tidak enak.

Kacang kedelai sebagai bahan dasar pembuatan tahu mempunyai kandungan protein sekitar 30-4\%. Dibandingkan dengan kandungan protein bahan pangan lain seperti daging, ikan dan telur, ternyata kedele merupakan bahan pangan yang mengandung protein tinggi. Pada garis besarnya proses pembuatan tahu ada dua bagian yaitu pembuatan ekstrak (susu kedele) dan pengyumpalan protein dari susu kedelai. Cara pembuatan susu kedelai meliputi perendaman, penggilingan kedele dan perebusan serta penyaringan dari bubur kedelai yang diperoleh.

Menurut (Cullison, 1979) pertumbuhan meliputi pertambahan besarnya otot, tulang, alat-alat tubuh dan jaringan konektif. Selanjutnya dikatakan Williamson dan Payne (1978) bahwa pertumbulan murni ditinjau dari sudut kimiawi adalah suatu penambahan dalam jumlah protein dan zat-zat mineral yang tertimbun dalam tubuh.

Penelitian ini dilakukan dengan tujuan untuk mengetahui pengarul pemanfaatan limbah tahu (air tahu) sebagai komboran pakan penggemukan sapi dan sekaligus memberi hasil tambahan dari pengusaha pembuat tahu.

\section{Materi Dan Metode}

Sapi jantan Peranakan Ongole (PO) berumur 12 bulan sebanyak 6 ekor dibagi secara acak menjadi 2 kelompok perlakuan ransum yaitu kelompok I (kontrol) dan kelompok II (Perlakuan) yang masingmasing kelompok terdiri dari 3 ekor sapi yang dikandangkan secara individual. Pakan yang diberikan terdiri dari rumput gajah dan komboran. (Komposisi ransum tertera pada Tabel 1).

Pakan diberikan dua kali/hari, yaitu setiap pagi dan sore hari. Jumlah pemberian pakan adalah sama selama penelitian. Limbah tahu (limbah II) diperoleh dari perusahaan tahu dengan skema prosessing seperti pada Gambar 1.

Parameter yang diukur meliputi: berat badan yang diperoleh dengan melakukan penimbangan setiap satu bulan sekali untuk menghitung kenaikan berat badan hitrian per ekor sapi. Konsumsi pakail yang diberikan ditimbang setiap hari. Berdasarkan perhitungan tabel maka dapat diketahui konsumsi bahan kering, protein dan konversi pakan. Limbah cair (air tahu) dan katul/dedak yang diberikan diambil sampel untuk diketahui komposisi kandungannya sebagai data pendukung.

Data kenaikan berat badan harian, dianalisis dengan menggunakan $t$. test (Astuti, 1980).

\section{Hasil Dan Pembahasan}

\section{Kandungan bahan kering}

Nilai gizi dari bahan pakan selain ditentukan oleh lengkapnya nutrien yang dikandungnya juga sangat dipengaruhi oleh tinggi rendahnya daya cerna dari bahan pakan tersebut serta nilai energinya (Sosroamidjojo dan Soeradji, 1981). Hasil 
Ca $30_{4}$


Limbah IT

SLSW KEME:A?

dicidititis

DI GLJWFAL WAS

Lipas

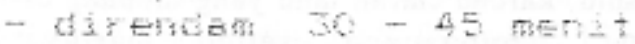

DIS3LTSE

DI BAETHE

- dibelas Wh mert

AMOAB YEDELA?

Limbats I

TABE

Bahan

Bekat

Air li

Rum

* Ana

- Ha

analis

dapat

(limb

kand

sebes

abu

dinila

Kons

DITEKANHTYFRES

erat $k$

kesel dalan

sapi I

dapat

Gambar 1. Skema proses pembuatan tahu

rerate

nyata 


\section{TABEL 1. SUSUNAN RANSUM (KG/HARI/EKOR)}

\begin{tabular}{lcc}
\hline \hline Bahan & kontrol & perlakuan \\
\hline Bekatul/dedak & 2,00 & 2,00 \\
Air tahu/limbah & - & 15,00 \\
Air minum & 15,00 & - \\
Rumput gajalı & 20,00 & 20,00 \\
\hline
\end{tabular}

TABEL 2. KANDUNGAN NUTRISI BAHAN PAKAN (\% BAHAN KERING)

\begin{tabular}{lrrrrrr}
\hline \hline Balan & BK & Abu & Lemak & Protein & SK & ETN \\
\hline Bekatul/Dedak* & 91,28 & 17,39 & 7,3 & 8,59 & 29,24 & 37,35 \\
Air limbah tahu* & 0,68 & 25,05 & 2,05 & 42,42 & 16,85 & 13,63 \\
Rumput gajah & 21,00 & 14,00 & 2,40 & 8,30 & 33,50 & 41,70 \\
\hline
\end{tabular}

- Analisa Laboratorium IMT Fak. Peternakan UGM

" Hartadi et al., 1980.

analisis dan kandungan nutrisi bahan pakan dapat dilihat pada Tabel 2 .

Pada tabel tampak bahwa air tahu (limbah industri tahu) masih mempunyai kandungan protein yang sangat tinggi yaitu sebesar $42,4 \%$, lemak $2,1 \%$ dan kandungan abu $25,1 \%$ merupakan bahan pakan yang dinilai gizinya cukup tinggi.

Konsumsi bahan kering

Konsumsi bahan kering pakan sangat erat kaitannya dengan konsumsi pakan secara keseluruhan dan kandungan bahan kering di dalamnya. Rerata konsumsinya bahan kering sapi Peranakan Ongole (PO) per hari per ekor dapat dilihat pada Tabel 3.

Dari Tabel 3 di atas diketahui bahwa rerata konsumsi bahan kering tidak bebeda nyata, tetapi tampak pada sapi-sapi kelompok perlakuan mengkonsumsi bahan kering dan nutrisi lebil tinggi dibanding dengan kelompok kontrol tanpa menggunakan air talu.

\section{Kenaikan berat badan harian}

Kenaikan berat badan harian (ADG) merupakan salah satu faktor yang diharapkan dalam pemeliharaan sapi potong. Kenaikan berat badan berhubungan dengan nilai ekonomi yang dihitung berdasarkan investasi yang ditanam dan nilai jual ternak. Pada Tabel 4 dapat diketahui rerata kenaikan berat badan harian pada sapi PO.

Rerata kenaikan berat badan pada Tabel 4 diatas secara statistik menunjukkan hasil yang berbeda tidak nyata. Pakan yang diberikan sejumlah $6,10 \mathrm{~kg}$ berat kering untuk setiap ekor per hari dengan kenaikan 
TABEL 3. KONSUMSI BAHAN KERING DAN NUTRISI (GR/EKOR/HARI)

TABE

\begin{tabular}{lrrrrrr}
\hline \hline Bahan & BK & Abu & Lemak & Protein & SK & ETN \\
\hline Bekatul/dedak & $1.825,60$ & 317,50 & 131,99 & 156,82 & 533,80 & 685,51 \\
Air limbah tahu & 102,75 & 25,74 & 2,11 & 43,59 & 17,31 & 14,00 \\
Rumput gajah & $4.200,00$ & 592,20 & 100,80 & $348,60.407,00$ & $.751,40$ \\
Air & - & - & - & - & - & - \\
\hline
\end{tabular}

Total

Kelompok I

(Kontrol) $)^{\circ}$

$6.025,60 \quad 909,70 \quad 232,79 \quad 505,42.940,80.436,91$

Kelompok II

(Perlakuan)

$\begin{array}{llll}6.128,35 & 935,44 & 234,90 & 549,011.958,12,450,91\end{array}$

- Tanpa air limbah talu

ADG

Bahan

Keunt

TABEL 4. PENIMBANGAN BERAT HIDUP SAPI, KENAIKAN BERAT BADAN HARIAN DAN RERATA KENAIKAN BERAT HIDUP (KG/HARI

Perbec sebesa

Catatum

\begin{tabular}{|c|c|c|c|c|c|c|}
\hline \multirow[b]{2}{*}{ No. sapi } & \multicolumn{3}{|c|}{ Kontrol (I) } & \multicolumn{3}{|c|}{ Perlakuan (II) } \\
\hline & 2 & 3 & 6 & I & 4 & 5 \\
\hline \multicolumn{7}{|l|}{$\begin{array}{l}\text { Penimbangan } \\
\text { berat sapi }\end{array}$} \\
\hline 1 & 214 & 180 & 191 & 213 & 192 & 184 \\
\hline 2 & 229 & 189 & 206 & 231 & 204 & 199 \\
\hline 3 & 232 & 212 & 228 & 255 & 219 & 217 \\
\hline 4 & 250 & 230 & 253 & 280 & 246 & 240 \\
\hline 5 & 266 & 239 & 268 & 310 & 261 & 268 \\
\hline $\begin{array}{l}\text { Pertambahan } \\
\text { berat hidup ( } \mathrm{kg} \text { ) }\end{array}$ & 52 & 59 & 77 & 97 & 69 & 84 \\
\hline ADG per hari $(\mathrm{kg})$ & 0,43 & 0,49 & 0,64 & 0,81 & 0,57 & 0,70 \\
\hline Reratas $^{\text {ns }}$ (kg/hari) & & 0,52 & & & 0,69 & \\
\hline
\end{tabular}




\section{TABEL 5. KONVERSI BAHAN KERING TERHADAP KENAIKAN BERAT BADAN}

\begin{tabular}{lll} 
Kelompok Konversi pakan & Efisiensi pakan \\
\hline
\end{tabular}

\begin{tabular}{lcc} 
I (Kontrol) & 11,58 & 0,086 \\
II (Perlakuan) & 8,88 & 0,113 \\
\hline
\end{tabular}

TABEL 6. PERHITUNGAN EKONOMIS PENGGUNAAN LIMBAH TAHU

\begin{tabular}{lllll}
\hline & Kelompok I & (Kontrol) & Kelompok II & (Perlakuan) \\
\hline ADG perhari & $0,52 \mathrm{~kg}$ & Rp1.820 & 0,69 & Rp2.415 \\
Bahan pakan & & Rp. 1.450 & & Rp1.400 \\
\hline Keuntungan & & Rp 370 & & Rp.1.015 \\
\hline
\end{tabular}

Perbedaan keuntungan kelompok I dan II sebesar Rp.645 per ekor per hari

Catatan: Harga pukun katul/dedak Rp. 300,00 per kg

Rumput gajah $R_{p}, 40,00$ per kg
air talıu
air biasa
kg berat supi PO Rp. 3.500

larga per $\mathrm{kg}$ berat sapi PO Rp.3.500

per hari $0,52 \mathrm{~kg}$. Sesuai dengan apa yang dilaporkan Utomo (1986) bahwa sapi PO yang diberi pakan berupa jerani padi, tepung Jaun lamtoro, dedak halus, kapu, garam dapur dan mineral dapat menghasilkan kenaikan berat badan $0,55 \mathrm{~kg}$ per ekor per hari. Tampak dari kelompok perlakuan dengan menggunakan air tahu dalam komboran kenaikan berat badan mencapai $0,69 \mathrm{~kg}$ sedang pada kelompok kontrol hanya $0,52 \mathrm{~kg}$ perharinya, walaupun secara statistik tidak berbeda ayata, tetapi dengan pemberian limbah tahu (air tahu) dalam pakan penggemukan sapi PO ternyata lebih baik dibanding dengan kontrol.

\section{Konversi pakan}

Pada penelitian ini macam pakan yang diberikan sama, yaitu rumput gajah dan dedak/katul hanya yang kelompok I dicampur dengan air biasa yang kelompok II dicampur dengan air tahu. Alasan untuk menghitung konversi pakan adalah untuk mengetahui efisiensi dalam pemberian pakan pada penggemukan sapi $\mathrm{PO}$, sehingga dapat dipilih macam yang tepat untuk pemberian pakan. Oleh karena itu, diharapkan dapat menurunkan konversi pakan.

Konversi pakan harian dihitung dengan menjumlah konsumsi bahan kering 
dengan pertambahan berat badan harian, Rp.645,00/ekor per hari. tampak pada Tabel 6 .

Dari Tabel 5 di atas tampak ransum perlakuan meskipun in take bahan kering lebih rendah dari kontrol, namun memberikan kenaikan berat badan harian yang lebih tinggi Jibanding perlakuan dan ini terlihat dari lebih rendahnya konversi pakan yaitu 8,8 pada perlakuan, sedangkan pada kontrol mencapai 11,58. Efisiensi pakan juga tampak lebih tinggi pada sapi yang diberi perlakuan $(0,113)$ sedangkan efisiensi dari kelompok kontrol yang hanya mencanai 0,086 .

Penggantian air minum dengan air limbah tahu dalam pakan penggemukan sapi PO ternyata memberikan sumbangan tambahan kandungan protein sebesar 43,59 gr/ckor/lari atau $6,86 \%$ dari total konsumsi protein pada ransum kontrol. Satu hal yang cukup menarik adalalı kemampuan sapi PO Jalam menggunakan limbah tahu untuk menaikkan berat badan harian. Kadar protein ransum hanya berbeda $9 \%$ namun mampu menaikkan lebilı dari $100 \mathrm{gr} / \mathrm{ekor} / \mathrm{hari}$ dibandingkan dengan ADG kelompok kontrol. Hal ini diduga kwalitas protein dalam limbah tahu masili cukup baik untuk penggemukan sapi PO.

\section{Perhitungan ckonomi}

Untuk mengetahui seberapa besar keuntungan secara ekonomis antara penggunaan air tahu pada pakan penggemukan sapi PO, maka dihitung jumlah pakan yang dihabiskan dikalikan dengan harga pakan dibandingkan dengan ADG yang dikalikan dengan harga per kilogram berat hidup sapi PO, maka dapat dilihat pada Tabel 6.

Dari Tabel 6 di atas tampak dengan pemberian pakan komboran yang menggunakan air tahu (limbah industri kecil tahu) untuk penggemukan sapi PO lebih besar keuntungan yang didapat, yaitu sebesar

\section{Daftar Pustaka}

Astuti, M, 1980. Rancangan Percobuan dan Analisu Statistik. Jilid I Bagian Pernuliaan Ternak Fokuitus Peternakan UGM, Yogyakartu.

Cullison, A.E. 1979. Fecels and Feeding. 2nd. ed. Reston Publ., Co., Restun Viginn.

Reksuluudiprodjo,S. 1981. Produksi Tannutun Hijauan Mukanan Ternak Tropik. Edisi 1. Cetakan, BP-FE, UGM, Yogyakarta.

Tillman, A.D.H. Hartadi, S. Reksohadiprodjo, S. Prawirukusumodan L. Leddosoekojo. 1984. llmu Makanau Ternak Dasar. Gadjah Mada Universily Press. Fakultas Peternakan Universitas Gadjuh Mada, Yogyakarta.

Utomo, R. 1986. Pengaruh Suplementasi Uree, Daun Lamtoro atau Amoniusi Uren Paa Jerami Pada Terhadap Kenaikan Berat Badan Sapi Peranakan Ongole. Thesis $S_{2}$ Fakultas Pasea Sarjana, UGM, Yogyakarta.

merup

kemai

melin

diketa

telah

pemel

substr

tingka

pencemaran lingkungan.

n, S. and W.J.A. Payne. 1978. An Introduction to Animal Husbandry in The Tropies. 3rd. ed. Longman Ine. New York. 